\title{
Fishing Livelihoods and Fisheries Governance
}

\begin{abstract}
This book centres on an understanding of fishing livelihoods within processes of historical change, and the social and political relationships within which they are embedded. Drawing on our research experience from the Asia-Pacific region, we examine where fishing livelihoods have come from, and where they are going. This introductory chapter introduces fishing livelihoods and the governance challenge that they face, before examining social science research in greater depth. We then develop the idea of a relational approach to fishing livelihoods, describing how they are shaped by wider political and economic trajectories, by local social relationships and by institutional structures.
\end{abstract}

Keywords Fishing livelihood $\bullet$ Political ecology $\bullet$ Wellbeing • Fisheries governance

In recent years the oceans have been subject to a profusion of regulatory, academic and private sector attention, as calls for a 'blue economy' are envisioned and executed across the world (Jouffray et al., 2020; Voyer et al., 2018). Characterised as the 'last frontier', oceans are presented as a dual opportunity for new forms of economic exploitation and renewed efforts to sustain ecological systems. Fisheries, and the livelihoods that they support, sit in an uneasy relationship to these transformations. While 
fishing ${ }^{1}$ has for generations provided food and livelihoods for millions of people throughout the world, increasingly it is challenged by newer coastal and ocean-based economic activities such as tourism and energy extraction, and by progressively tightening forms of governance that seek to reduce its environmental effects. The consequences of such developments are felt in different ways across the diverse social groups involved in fishing.

This book centres on an understanding of fishing livelihoods within processes of historical change, and the social and political relationships within which they are embedded. Drawing on our research experience from the Asia-Pacific region, we examine where fishing livelihoods have come from, and where they are going. Developing a 'relational' view of fishing livelihoods, we examine how they are shaped by wider political and economic trajectories, by local social relationships and by institutional structures. We discuss how such an understanding of fishing livelihoods can contribute to more ecologically sustainable and socially equitable governance strategies.

\section{FisHiNG LivELIHOODS}

Across the world, fisheries provide direct employment for around $38.98^{2}$ million people (Food and Agriculture Organization [FAO], 2020). In many coastal regions of the world, and particularly in many low-income contexts, fishing livelihoods remain the primary economic activity. Globally, they make significant contributions towards food and nutrition security, and are particularly important as a source of micronutrients, including vitamin A, omega-3, zinc, iron, calcium and selenium (Hicks et al., 2019).

Fishing livelihoods are characterised by their diversity, flexibility and dynamism, responding to changing environmental, climatic and economic conditions. It is common to differentiate between small-scale and largescale fisheries, yet there are no universally accepted criteria that distinguish between these sectors. Large-scale fisheries tend to involve larger-sized vessels that use advanced or capital-intensive technologies (e.g., trawls, purse seines), wage labour and larger firms. The livelihoods in large-scale fisheries are as employed crew, or crew who are paid a portion of the value of the catch. In contrast, small-scale fisheries tend to be more labour

${ }^{1}$ By 'fish' we mean all seafood (e.g., including crustaceans, shellfish, etc.) in addition to fish. We do not include discussion of inland fishing or fishing livelihoods in this book.

${ }^{2}$ This includes part-time, seasonal and permanent work. 
intensive and involve the use of smaller vessels and less capital-intensive gears (e.g., handlines, nets that can be pulled in by hand) that operate closer to shore, and are operated by individuals, households or small groups from within coastal villages. While small-scale fishers tend to sell their fish in local or domestic markets, or consume it directly, many are also involved in export operations. For example, Indonesian fishers who work alone from wooden vessels only a couple of metres long using handlines catch yellowfin tuna sold as steaks in North America. In practice, the distinctions between small-scale and large-scale fisheries blur considerably (Johnson et al., 2005). Small-scale fisheries are estimated to account for more than 90 per cent of fishers and fish workers (i.e., in trading and processing) (Kelleher et al., 2012), the vast majority of which are located in developing countries. While fishing is commonly thought of in relation to marine spaces, inland fisheries (the 'forgotten fisheries'; Cooke et al., 2016) account for about 12.5 per cent of total capture fisheries production (Funge-Smith \& Bennett, 2019).

Beyond work in fishing alone, many livelihoods (over 100 million in total; Kelleher et al., 2012) are based around, partly or in whole, the diverse activities along the value chain-seafood processing, marketing, trading, boat and gear construction, servicing vessels and so on. Much work goes into preparing and maintaining the inputs for fishing, especially in boat and gear construction and maintenance. Post-harvest, seafood is processed in various ways. In large-scale fisheries, such as for tuna, processing plants and factories employ workers to prepare the fish according to different market demands, such as loins, cans or fillets. For example, in North-Eastern China, vast numbers of whitefish from Russia and other northern economies are imported, filleted and packaged, and then reexported (Clarke, 2009). In small-scale fisheries, where access to refrigeration is less common, fish are commonly dried, smoked and/or salted.

Fish is one of the most highly traded commodities (Gephart \& Pace, 2015 ), and this trade occurs at multiple scales. From local markets in villages, to provincial town centres, to major national markets and overseas, fish are typically transported over land, sea and air through complex networks of traders, agents and firms. Internationally, fish are exported to major markets including China, Japan, the European Union (EU) and North America, frequently through complex trade routes and intermediary countries that make it difficult to track (Stoll et al., 2018). Wholesalers, retailers and restaurants then provide livelihoods for further nodes along fisheries value chains. 
The current state of fisheries and their associated value chains and livelihoods is not a static picture, but is a reflection of the wider historical conditions that have led to this point. Fishing of various types has been prevalent for millennia, with political and economic developments shaping its character differently in different times and places. For example, the expansion of Chinese trade networks from the late seventeenth century led to the rapid uptake of fishing for products for the Chinese market, such as dried sea cucumbers. By the mid-nineteenth century, polities such as the Sulu Sultanate were centred on this economy (Warren, 1981). As domestic markets for fish products grew with increased populations and consumer demand, this stimulated the rise of specialised fishing communities along coastal South-East Asia (Spoehr, 1984). The foundations for industrial fisheries in South-East Asia were laid in the late 1800s and early twentieth century under European rule, and then industrial fisheries were established under Japanese imperial expansion southward in the decades preceding World War II (Butcher, 2004; Chen, 2008).

From the second half of the twentieth century, the intensification of globalisation brought dramatic changes to fishing livelihoods (Butcher, 2004). Increasing demand for fish in markets such as the EU and the United States (US) stimulated production, while new fishing technologies emerged to increase the efficiency of catch. Fisheries expanded geographically into new frontiers and intensified in locations where they had already been present, including deeper down the water column. In many locations, fishing livelihoods became transformed into a market-oriented activity based on trade at local, national and global scales. Globalisation, or the process of 'time-space compression', as Harvey (1989) terms it, has increased the scale, pace and diversity of fishing activities around the world (Eriksson et al., 2015; Gephart \& Pace, 2015).

Fishing livelihoods are not simply an economic process of harvesting, processing and trading to generate income. Such economic activities are embedded within (Granovetter, 1985) and intersect with diverse social relationships. The particular manner by which fishing livelihoods are operated reflects wider social structures, which vary tremendously across geography and over time. For example, in many societies, fishing livelihoods are strongly gendered-men are frequently associated with fishing from boats further from shore, and women with near-shore fishing, gleaning, processing and marketing. Group identities such as ethnicity, caste, migration or religion or status can influence who is involved in fishing. For example, in South-East Asia, Sama-Bajau people are strongly associated 
with fishing practices. This association is often pejorative, and they are typecast as ignorant, poor and environmentally destructive (Lowe, 2000). In the Philippines, migrants from the Visayan group of islands are closely associated with fishing in some parts of the country where they lacked access to land for farming (Eder, 2003), and seafood exporters tend to have ethnic Chinese links. Many of the 'Japanese' fishers who worked throughout Asia and northern Pacific Island countries in the first half of the twentieth century were Okinawan, who through the forcible incorporation of Okinawa into the Japanese Empire in the 1870s were left destitute and had to travel to find livelihoods (Tomiyama, 2002).

\section{The Governance Challenge}

The environmental consequences of the progressive expansion and intensification of fisheries around the world have been significant. While there is much variability (Hilborn et al., 2020), in many cases, fisheries stocks have been overexploited. In 2017, the fraction of fish stocks considered by the FAO (2020) to be unsustainably fished was 34.2 per cent. Between 1950 and 2015, the catch-per-unit effort decreased by over 80 per cent in most countries (Rousseau et al., 2019). In many cases, the very viability of fishing livelihoods is under threat, following the trajectory of North American cod fisheries (Binkley, 2002).

Beyond the fish themselves, fish habitat and broader ecosystems have been substantially degraded. Destructive fishing gears such as dynamite, pollution, plastic debris, coastal infrastructure, shipping and agricultural run-off have negatively affected many marine ecosystems. Increasingly, the effects of climate change are being felt. The decline of coral reef systems, such as the Great Barrier Reef, is being driven primarily by coral bleaching caused by climate change (Hughes et al., 2017). Under a scenario of continued high emissions, the maximum catch potential of tropical fish stocks in some tropical exclusive economic zones (EEZs) is projected to decline by up to 40 per cent (Lam et al., 2020). Climate change is also projected to dramatically alter marine ecosystems through additional stresses such as ocean acidification, deoxygenation, changing patterns of nutrient supply and storms (Henson et al., 2017).

In this context of environmental decline, fishing livelihoods have been increasingly subject to attempts to govern their nature and extent. A central concern of much governance has focused on the need to sustainably manage fisheries as natural resources. At the local level, systems of 
customary marine tenure have regulated access to fishing grounds in many places (Foale et al., 2011). At a higher scale, state-based governance regimes have increasingly aimed to manage and regulate capture fisheries and the marine spaces where they are found (Campling \& Havice, 2018). Through the twentieth century states exerted national claims over territorial waters (usually 12 nautical miles), and progressively expanded their claims over greater distances from the land. The United Nations Convention on the Law of the Sea (UNCLOS) emerged to codify sovereignty over EEZs in the early 1980s, and formally came into force from 1994, demarcating sovereign rights over waters $200 \mathrm{~nm}$ out from the coast.

In many richer countries, fisheries have been progressively managed through the use of economic instruments, founded on concepts such as maximum sustainable yield and maximum economic yield. Tools such as total allowable catches (TACs), licences and quotas are employed to regulate access to resources according to biologically determined parameters. Such instruments intersect with other regulations, including seasonal or other temporal closures, or gear restrictions. In recent decades, the concept of ecosystem-based fisheries management (EBFM) has become widely accepted, where fisheries are managed not as a single, isolated stock but with reference to the broader ecosystem of which they are part (Pikitch et al., 2004). Various forms of marine protected areas (MPAs) that spatially regulate access marine zones have become widespread as part of this.

Since the 2000s, the rise of market-based 'private governance' through various forms of certification and eco-labelling has become more prevalent (Bush \& Oosterveer, 2019). The largest eco-label, the Marine Stewardship Council (MSC), now covers approximately 15 per cent of global fish catch (Le Manach et al., 2020). As consumers have become more aware of overfishing as a problem, in large part due to campaigns by environmental NGOs, some brands and retailers have sought to enhance their reputation by aligning themselves with the sustainable seafood movement. Others have used market-based initiatives to protect their reputation by avoiding association with destructive fishing practices.

More recently, a dominant governance paradigm appears to be coalescing around the idea of a 'blue economy'. While there is much variation in how this term is used (Silver et al., 2015), the core proposal is to manage marine resources in a way that integrates ecological sustainability and economic profitability. As economic and political actors increasingly seek to access marine resources for ecologically sustainable uses that generate economic value, fisheries are becoming pressured both by governance regimes 
and by newer sectors. In some cases, fishing livelihoods are being pushed out, as coastal land and waters are appropriated for tourism, energy and conservation (Barbesgaard, 2018; Bavinck et al., 2017).

All too commonly, much fisheries governance struggles to be effective in protecting both the fish stocks and the livelihoods that rely on them. Fishing itself is inherently difficult to govern because the act of fishing takes place out at sea. The challenge is particularly acute in low-income contexts, where the state has few resources available for management, implementation and enforcement, and in many instances there are few viable alternative livelihoods (Barclay et al., 2019). Small-scale fisheries typically tend to be widely dispersed and fragmented across coastlines, and in practice tend to be informally governed at more local scales (Steenbergen et al., 2019). They are frequently missed in formal state statistics, and as a result are less visible in policy-a state of affairs several organisations and programmes are aiming to change (e.g., Too Big to Ignore, 2013).

Yet, there are also more fundamental, underlying reasons behind the challenges of fisheries governance that go well beyond the technical challenges of resources, implementation and enforcement in remote locations. Much fisheries governance proceeds from a standpoint informed by a narrow set of perspectives, where livelihoods are understood in terms of how much dollar value fisheries generate, and/or the effects of fisheries on fish stocks and marine habitats. Financial revenue and the volume of landed catch become the two crucial metrics by which fisheries are assessed, and the role of fisheries management is usually framed in legislation as promoting viable industries and looking after fish stocks.

The consequences of such perspectives are twofold. First, they narrow our understanding of what a fishing livelihood is: they are 'reductionist' in that they reduce or limit the scope of understanding a fishing livelihood to the acts of fishing and selling, and indeed usually only to the formal, easily visible elements of seafood trade. As such, they tend to gloss over or miss key aspects of fishing livelihoods. The political and economic contexts of fishing livelihoods (including their integration with other forms of economic activity), the historical processes leading up to their contemporary configurations, and the diversity of social practices and identities associated with them are all central components of a fishing livelihood. As Johnson et al. (2005: 84) note, 'when looking at capture fisheries as a livelihood it becomes apparent that a strict division between the taking and landing of fish and other aspects of life is hard to maintain'. 
Second, and relatedly, viewing fishing livelihoods through a lens that emphasises gross economic value and environmental effects leads to the formation of particular forms of governance that do not address some of these important aspects of fishing livelihoods. For example, small-scale fisheries tend to be more associated with marginalised groups, such as women or poorer people. The livelihood functions of small-scale fisheries can, therefore, be characterised more effectively through the generation of 'welfare', in contrast or in addition to 'wealth' (Béné et al., 2010). In these contexts, policies that aim to promote the generation of wealth alone can cause significant negative social effects (Cohen et al., 2019). Beyond the ethical dilemmas of these negative social effects, there are also environmentally pragmatic consequences of pursuing governance visions that ignore fishing livelihood contexts. When policies do not attain broad popular support, they fail to attain legitimacy (Coulthard et al., 2011; Jentoft, 2000). Governance that is illegitimate can have poor compliance. By ignoring the wider aspects of fishing livelihoods, governance is less likely to be legitimate, and subsequently less likely to attain its objectives.

\section{Fisheries as a Social Process}

In contrast to perspectives that emphasise gross economic value and environmental effects of fisheries, there is a long tradition of social science that views fisheries as a fundamentally social process. Historians, social anthropologists and others have shown the intricate links between fishing and societies (Binkley, 2002; Clark, 2017; Firth, 1966; Probyn, 2016), documenting cultural traditions related to fishing (Allison et al., 2020), customary and contemporary forms of marine tenure that regulate access to marine spaces (Acheson, 1988; Hviding, 1996), the social relations between different groups of people involved in fishing (Pálsson, 1994), and the non-economic factors that drive people to pursue fishing as a livelihood (Pollnac \& Poggie, 2008). In recent decades, much fisheries social science has taken an explicitly applied approach, seeking to apply insights about human behaviour to the challenge of improving fisheries governance (Berkes et al., 2001; Kooiman et al., 2005; Kraan \& Linke, 2020; McGoodwin, 1995). Organisations such as the Centre for Maritime Studies, FAO, WorldFish and the Too Big to Ignore research network have developed significant bodies of literature around small-scale fisheries (Jentoft, 2019), the theory and practice of interactive governance (Kooiman et al., 2005) and human rights-based approaches to fisheries 
(Allison et al., 2012). Many donor-funded fisheries projects in developing countries routinely include social science as part of their activities (e.g., Christie et al., 2005), and academic fields emerging from the environmental sciences (e.g., literature on social-ecological systems and resilience) now engage with questions traditionally addressed by social scientists, such as those relating to poverty and participation (e.g., Blythe et al., 2017). The increasing emphasis on interdisciplinary and multidisciplinary science has meant that the field of 'marine social science' (\#marsocsci) now incorporates a diverse set of perspectives.

Within this field of scholarship, we focus on three specific threads of literature that are particularly relevant for our discussion on fishing livelihoods: the sustainable livelihoods approach (SLA), the social wellbeing approach and political economy perspectives. The SLA conceived of a livelihood comprised of 'the capabilities, assets (including both material and social resources) and activities required for a means of living' (Chambers \& Conway, 1992: 6). Subsequently highly influential, in part because of its adoption by the United Kingdom's Department for International Development, livelihood assets were conceptualised as a 'pentagon' of capitals (natural, social, human, physical and financial). Among the key emphases of the SLA was a focus on diversification as a positive strategy to spread risk, and the SLA approach was subsequently used in the fisheries sector in diverse academic and policy contexts (Allison \& Ellis, 2001; Allison \& Horemans, 2006). While the SLA has subsequently been subject to critique for its relative neglect of politics and power (De Haan \& Zoomers, 2005; Scoones, 2009), its emphasis on the material aspects of livelihoods (Carr, 2013) and on local-scale processes and structure (Carr, 2015 ), it remains a common approach in many fisheries governance interventions in developing countries (e.g., Apine et al., 2019).

Building on a diverse set of traditions in development studies and quality-of-life studies - including the SLA - the 'three-dimensional' or 3D social wellbeing approach emerged in fisheries as a way to understand fishing livelihoods more broadly than gross economic totals (Coulthard et al., 2011; Weeratunge et al., 2014). While 'objective' values (e.g., economic contributions) are still examined in this approach, attention is also paid to subjective values (e.g., job satisfaction) and relational values (e.g., relationships between different groups of people involved in the fishery). The goal is to assess a fishery not just in terms of economic value or environmental impact, but also in terms of a wider suite of values (Johnson et al., 2018). With this framing of fisheries, the governance question becomes 
one of how to design interventions that adequately capture the wider total of contributions that fisheries make (Song, 2018). Therefore, both the SLA and wellbeing approaches to understanding livelihoods take us a long way from understanding a fishing livelihood as the act of fish harvesting alone.

In the fisheries sector, much work in the broad tradition of political economy has emerged that challenges conventional explanations of resource decline as the 'tragedy of the commons', referring instead to wider systemic factors such as patterns of capital accumulation (Campling et al., 2012; Longo et al., 2015; Mansfield, 2004). However, as Belton (2016) notes, there remains considerable scope to bring together studies of social wellbeing and political economy. While studies of agrarian change that investigate the drivers and outcomes of livelihood change have long been prominent in journals such as the Journal of Peasant Studies and the Journal of Agrarian Change, less political economy attention has been paid to coastal spaces (Campling \& Colás, 2018; Fabinyi et al., 2019).

\section{Our Approach}

Focusing on the intersection between these approaches-livelihoods, wellbeing and political economy-our approach can broadly be seen as fitting in under the rubric of 'political ecology' (Perreault et al., 2015). This is a field notable for its diversity of concepts and approaches, but there are several key aspects of political ecology that inform our approach.

First is an emphasis on multiple scales. While recognising that scale itself is a social construct (Neumann, 2009), a core tenet of early political ecology from the 1980s has been to emphasise that the factors driving human behaviour in relation to the environment are often located at regional or global scales (Blaikie \& Brookfield, 1987). This emphasis intersected with the long-overdue recognition in social anthropology that the social relations structuring everyday life frequently had as much or more to do with dynamic processes of global economic transformation over time, instead of what were typically depicted as static local cultures (Gupta \& Ferguson, 1997; Wolf, 1983). Carr (2015: 336) notes that 'a political ecological approach to livelihoods analysis explains local livelihood decisions and their sustainability through locally specific materializations of translocal economic, political, and environmental processes and structures'. 
A second notable feature of political ecology from at least the 1990s has been to analyse how material and symbolic orders interact (Hornborg et al., 2013; Peet \& Watts, 1996). Social identities, ideas and cultural values - such as the role of gender (Rocheleau et al., 1996), attitudes towards the environment (Agrawal, 2005), or the roles of dominant environmental narratives (Fairhead \& Leach, 1996; Forsyth, 2014) —all strongly influence human-environment relations. Relatedly, a third feature of much political ecology has been attention to the role of political actors, including the state, and political struggles over the environment (Robbins, 2012). From this perspective, conflicts over access to and exclusion from environmental resources are not unusual or aberrant processes, but the norm when studying 'politicised environments' (Bryant \& Bailey, 1997; Le Billon \& Duffy, 2018).

This book adopts what we term as a relational approach to fishing livelihoods. While the concept of relationality is used in diverse ways, here we draw broadly on a philosophical tradition that emphasises the roles of process, experience and relations as fundamental categories (Dewey, 1929; Ingold, 2015, 2018b; Whitehead, 1929). As Ingold (2018a: 100, 101-102) describes it, this is a view that sees 'relations not just as derivative of society, but as the very fabric of social life. ... In life, relations are not given in advance but have continually to be performed'. We use the term relational to emphasise that a livelihood is best understood as a set of activities operating in relationships with other processes and people over time, and that livelihoods are shaped by people's relational positions in society.

While closely related to the social wellbeing concept of relationality (see Johnson, 2018), we also draw explicitly on a political economy tradition of work on poverty. Specifically, we draw on Mosse's (2010) conceptualisation of poverty as a consequence of two sets of social relationships-first, historically developed economic and political relations, and second, social categorisation and identity (see also Harriss, 2009). While a 'fishing livelihood' is by no means always a life of poverty (Bavinck, 2014), and the concept of livelihood is quite different to the concept of poverty, we suggest that they are similar in that both can be effectively understood as centred on a set of social relationships that change over time, instead of as a discrete attribute of an individual or household.

In addition to the wider processes of political-economic change and the microsocial relations highlighted by Mosse, we suggest that a third key relationship a fishing livelihood has is with the specific institutional 
arrangements that govern access to and exclusion from fisheries resources (Hall et al., 2011; Li, 2007). While these three sets of relationships overlap with each other, the aim is to combine what are broadly Marxian ideas about 'adverse incorporation' into the global economy (e.g., McCarthy, 2010), with broadly Weberian ideas about social exclusion (e.g., Hall et al., 2011) and critical accounts of governance ( $\mathrm{Li}, 2007)$ in complementary ways (Mosse, 2010). Understanding a livelihood in terms of the social relationships and structures that sustain and reproduce it embeds the concept in processes of change. We view livelihoods as constituted through their relations with the wider political economy, the microsocial climate and the institutional context.

The Asia-Pacific is an important site to study fishing livelihoods for several reasons. Asia alone provides 30.77 million out of the 38.98 million employed in fisheries worldwide (FAO, 2020). While the Pacific is far less densely populated, it generates some of the most globally significant fisheries in the form of large-scale tuna fisheries. The area as a whole is host to the 'Coral Triangle', a region defined by the highest marine biodiversity in the world. While we draw on secondary literature where relevant, the book draws directly on our own research experience across several countries. Fabinyi has conducted long-term research on fishing and coastal livelihoods in the Philippines since 2005, especially in Palawan and Mindoro. ${ }^{3}$ $\mathrm{He}$ also has research experience on fishing livelihoods in Indonesia, Malaysia, Papua New Guinea (PNG) and Solomon Islands, and on seafood markets and consumption in China. Barclay started researching livelihoods in the tuna industry in Japan and the Solomon Islands in 1997, other Pacific Island countries, including PNG since 2005, and Indonesia since 2016. She has also investigated fisheries and aquaculture livelihoods in Australia (in South Australia, New South Wales, Victoria and Queensland). Both of us rely primarily on qualitative research, at different times using semi-structured interviews, participant observation and historical analysis. Since we draw on selected case studies from the countries where we have worked, the book is not a comprehensive analysis of the entire Asia-Pacific, but focuses largely on livelihoods in Island South-East Asia and the Pacific (see Fig. 1.1). Another major omission is of inland

\footnotetext{
${ }^{3}$ Mindoro is composed of two provinces, Occidental and Oriental Mindoro, while Palawan is currently proposed to be split into three provinces: Palawan del Norte, Palawan Oriental and Palawan del Sur. In this book, Mindoro and Palawan are collectively referred to as the Western Philippines.
} 
1 FISHING LIVELIHOODS AND FISHERIES GOVERNANCE 13

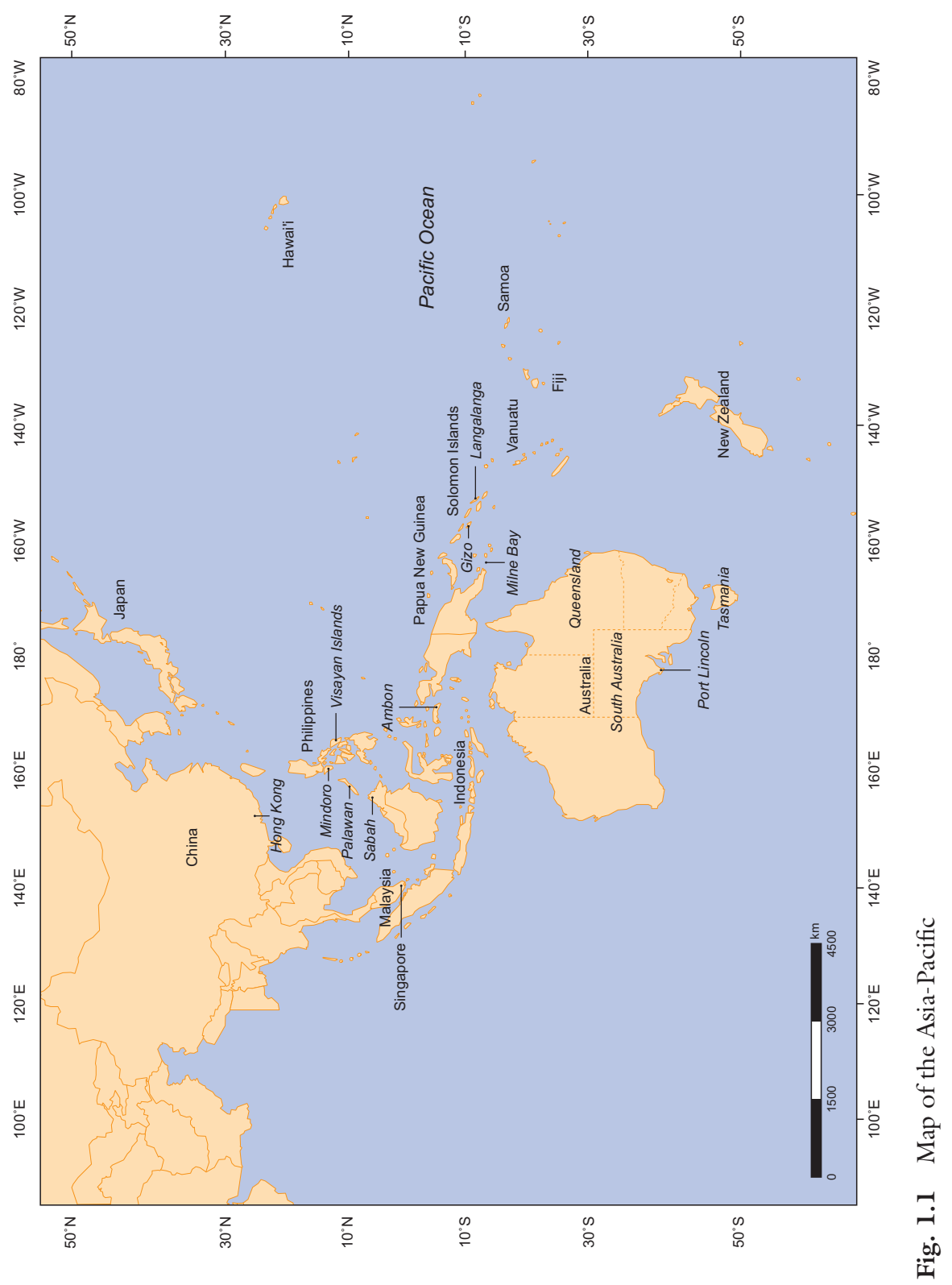


fishing livelihoods - an important topic deserving of greater levels of research and policy investment, particularly in the Asia-Pacific (Cooke et al., 2016; Funge-Smith \& Bennett, 2019).

The following chapters draw on selected case studies from our research to demonstrate a relational approach to understanding fishing livelihoods. Chapter 2 discusses how fishing livelihoods are shaped by wider processes of capitalist transformation, using cases of the Philippines and PNG. In Chap. 3 we examine how fishing livelihoods relate to social processes of access and exclusion, particularly status and gender. Chapter 4 discusses how different models and practices of governance can shape livelihoods, drawing on cases from Australia and Indonesia. Chapter 5 concludes with a discussion of how the approach taken in this book can be practically used to contribute to improved governance. There are many areas of overlap, and the distinctions between the subject matters of the chapters blur considerably in practice. Our overall goal is to highlight concrete examples of how fishing livelihoods relate to broader political-economic processes, social relationships and institutional contexts, and the implications of such a perspective for improving governance for sustainable and equitable fishing livelihoods.

\section{REFERENCES}

Acheson, J. M. (1988). The lobster gangs of Maine. University Press of New England. Agrawal, A. (2005). Environmentality: Technologies of government and the making of subjects. Duke University Press.

Allison, E. H., \& Ellis, F. (2001). The livelihoods approach and management of small-scale fisheries. Marine Policy, 25(5), 377-388.

Allison, E. H., \& Horemans, B. (2006). Putting the principles of the sustainable livelihoods approach into fisheries development policy and practice. Marine Policy, 30(6), 757-766.

Allison, E. H., Ratner, B. D., Åsgård, B., Willmann, R., Pomeroy, R., \& Kurien, J. (2012). Rights-based fisheries governance: From fishing rights to human rights. Fish and Fisheries, 13(1), 14-29. https://doi.org/10.1111/ j.1467-2979.2011.00405.x

Allison, E. H., Kurien, J., Ota, Y., Adhuri, D. S., Bavinck, J. M., CisnerosMontemayor, A., Olukoju, A., et al. (2020). The human relationship with our ocean planet. Washington, DC: World Resources Institute. Retrieved December 10, 2020, from https://www.oceanpanel.org/blue-papers/Human RelationshipwithOurOceanPlanet 
Apine, E., Turner, L. M., Rodwell, L. D., \& Bhatta, R. (2019). The application of the sustainable livelihood approach to small scale-fisheries: The case of mud crab Scylla serrata in south West India. Ocean \& Coastal Management, $170,17-28$.

Barbesgaard, M. (2018). Blue growth: Savior or ocean grabbing? The Journal of Peasant Studies, 45(1), 130-149. https://doi.org/10.1080/0306615 0.2017.1377186

Barclay, K., Fabinyi, M., Kinch, J., \& Foale, S. (2019). Governability of high-value fisheries in low-income contexts: A case study of the sea cucumber fishery in Papua New Guinea. Human Ecology, 47(3), 381-396. https://doi. org/10.1007/s10745-019-00078-8

Bavinck, M. (2014). Investigating poverty through the lens of riches-Immigration and segregation in Indian capture fisheries. Development Policy Review, 32(1), 33-52. https://doi.org/10.1111/dpr.12042

Bavinck, M., Berkes, F., Charles, A. T., Dias, A. C. E., Doubleday, N., Nayak, P. K., \& Sowman, M. (2017). The impact of coastal grabbing on community conservation-A global reconnaissance. Maritime Studies, 16(1), 8. https:// doi.org/10.1186/s40152-017-0062-8

Belton, B. (2016). Shrimp, prawn and the political economy of social wellbeing in rural Bangladesh. Journal of Rural Studies, 45, 230-242.

Béné, C., Hersoug, B., \& Allison, E. H. (2010). Not by rent alone: Analysing the pro-poor functions of small-scale fisheries in developing countries. Development Policy Review, 28(3), 325-358. https://doi.org/10.1111/j.1467-7679. 2010.00486.x

Berkes, F., Mahon, R., McConney, P., Pollnac, R., \& Pomeroy, R. (2001). Managing small-scale fisheries: Alternative directions and methods. IDRC.

Binkley, M. E. (2002). Set adrift: Fishing families. University of Toronto Press.

Blaikie, P., \& Brookfield, H. (Eds.). (1987). Land degradation and society (1st ed.). Routledge.

Blythe, J., Cohen, P. J., Eriksson, H. B., Cinner, J. E., Boso, D., Schwarz, A.-M., \& Andrew, N. L. (2017). Strengthening post-hoc analysis of community-based fisheries management through the social-ecological systems framework. Marine Policy, 82, 50-58.

Bryant, R. L., \& Bailey, S. (1997). Third world political ecology. Routledge.

Bush, S. R., \& Oosterveer, P. (2019). Governing sustainable seafood. Routledge.

Butcher, J. G. (2004). The closing of the frontier: A history of the marine fisheries of Southeast Asia, c. 1850-2000. Institute of Southeast Asian Studies.

Campling, L., \& Colás, A. (2018). Capitalism and the sea: Sovereignty, territory and appropriation in the global ocean. Environment and Planning D: Society and Space, 36(4), 776-794. https://doi.org/10.1177/0263775817737319

Campling, L., \& Havice, E. (2018). The global environmental politics and political economy of seafood systems. Global Environmental Politics, 18(2), 72-92. https://doi.org/10.1162/glep_a_00453 
Campling, L., Havice, E., \& McCall Howard, P. (2012). The political economy and ecology of capture fisheries: Market dynamics, resource access and relations of exploitation and resistance. Journal of Agrarian Change, 12(2-3), 177-203. https://doi.org/10.1111/j.1471-0366.2011.00356.x

Carr, E. R. (2013). Livelihoods as intimate government: Reframing the logic of livelihoods for development. Third World Quarterly, 34(1), 77-108. https:// doi.org/10.1080/01436597.2012.755012

Carr, E. R. (2015). Political ecology and livelihoods. In T. Perreault, G. Bridge, \& J. McCarthy (Eds.), The Routledge handbook of political ecology (pp. 332-342). Routledge.

Chambers, R., \& Conway, G. (1992). Sustainable rural livelihoods: Practical concepts for the 21st century. IDS Discussion Paper no. 296. Institute of Development Studies.

Chen, H. (2008). Japan and the birth of Takao's fisheries in Nanyo, 1895-1945. International Journal of Maritime History, 20(1), 133-152. https://doi. org/10.1177/084387140802000107

Christie, P., Lowry, K., White, A. T., Oracion, E. G., Sievanen, L., Pomeroy, R., Pollnac, R., et al. (2005). Key findings from a multidisciplinary examination of integrated coastal management process sustainability. Ocean \& Coastal Management, 48(3-6), 468-483. https://doi.org/10.1016/j.ocecoaman. 2005.04.006

Clark, A. (2017). The catch: The story of fishing in Australia (1st ed.). National Library of Australia.

Clarke, S. (2009). Understanding China's fish trade and traceability. TRAFFIC East Asia.

Cohen, P. J., Allison, E. H., Andrew, N. L., Cinner, J., Evans, L. S., Fabinyi, M., Jentoft, S., et al. (2019). Securing a just space for small-scale fisheries in the blue economy. Frontiers in Marine Science, 6, 171. https://doi.org/10.3389/ fmars.2019.00171

Cooke, S. J., Allison, E. H., Beard, T. D., Jr., Arlinghaus, R., Arthington, A. H., Bartley, D. M., Cowx, I. G., et al. (2016). On the sustainability of inland fisheries: Finding a future for the forgotten. Ambio, 45(7), 753-764. https://doi. org/10.1007/s13280-016-0787-4

Coulthard, S., Johnson, D., \& McGregor, J. A. (2011). Poverty, sustainability and human wellbeing: A social wellbeing approach to the global fisheries crisis. Global Environmental Change, 21(2), 453-463.

De Haan, L., \& Zoomers, A. (2005). Exploring the frontier of livelihoods research. Development and Change, 36(1), 27-47. https://doi.org/10.1111/j.0012155X.2005.00401.x

Dewey, J. (1929). Experience and nature. Open Court Publishing.

Eder, J. F. (2003). Of fishers and farmers: Ethnicity and resource use in coastal Palawan. Philippine Quarterly of Culture and Society, 31(3), 207-225. 
Eriksson, H., Österblom, H., Crona, B., Troell, M., Andrew, N., Wilen, J., \& Folke, C. (2015). Contagious exploitation of marine resources. Frontiers in Ecology and the Environment, 13(8), 435-440. https://doi.org/ $10.1890 / 140312$

Fabinyi, M., Dressler, W., \& Pido, M. (2019). Access to fisheries in the maritime frontier of Palawan Province, Philippines. Singapore Journal of Tropical Geography, 40(1), 92-110.

Fairhead, J., \& Leach, M. (1996). Misreading the African landscape: Society and ecology in a forest-savanna mosaic (Vol. 90). Cambridge University Press.

Firth, R. (1966). Malay fishermen: Their peasant economy (2nd ed.). Routledge \& Kegan Paul.

Foale, S., Cohen, P., Januchowski-Hartley, S., Wenger, A., \& Macintyre, M. (2011). Tenure and taboos: Origins and implications for fisheries in the Pacific. Fish and Fisheries, 12(4), 357-369. https://doi.org/10.1111/ j.1467-2979.2010.00395.x

Food and Agriculture Organization. (2020). The state of world fisheries and aquaculture 2020:Sustainabilityinaction.FAO.https://doi.org/10.4060/ca9229en

Forsyth, T. (2014). Public concerns about transboundary haze: A comparison of Indonesia, Singapore, and Malaysia. Global Environmental Change, 25, 76-86.

Funge-Smith, S., \& Bennett, A. (2019). A fresh look at inland fisheries and their role in food security and livelihoods. Fish and Fisheries, 20(6), 1176-1195. https://doi.org/10.1111/faf.12403

Gephart, J. A., \& Pace, M. L. (2015). Structure and evolution of the global seafood trade network. Environmental Research Letters, 10(12), 125014.

Granovetter, M. (1985). Economic action and social structure: The problem of embeddedness. American Journal of Sociology, 91(3), 481-510. https://doi. org $/ 10.1086 / 228311$

Gupta, A., \& Ferguson, J. (Eds.). (1997). Culture, power, place: Explorations in critical anthropology. Duke University Press.

Hall, D., Hirsch, P., \& Li, T. M. (2011). Powers of exclusion: Land dilemmas in Southeast Asia. University of Hawai'i Press.

Harriss, J. (2009). Bringing politics back into poverty analysis. In T. Addison, D. Hulme, \& R. Kanbur (Eds.), Poverty dynamics: Interdisciplinary perspectives (pp. 205-224). Oxford University Press.

Harvey, D. (1989). The condition of postmodernity. Blackwell.

Henson, S. A., Beaulieu, C., Ilyina, T., John, J. G., Long, M., Séférian, R., Sarmiento, J. L., et al. (2017). Rapid emergence of climate change in environmental drivers of marine ecosystems. Nature Communications, 8(1), 1-9. https://doi.org/10.1038/ncomms14682

Hicks, C. C., Cohen, P. J., Graham, N. A., Nash, K. L., Allison, E. H., D'Lima, C., MacNeil, M. A., et al. (2019). Harnessing global fisheries to tackle micronutrient deficiencies. Nature, 574(7776), 95-98. https://doi.org/10.1038/ s41586-019-1592-6 
Hilborn, R., Amoroso, R. O., Anderson, C. M., Baum, J. K., Branch, T. A., Costello, C., Kurota, H., et al. (2020). Effective fisheries management instrumental in improving fish stock status. Proceedings of the National Academy of Sciences, 117(4), 2218-2224. https://doi.org/10.1073/pnas.1909726116

Hornborg, A., Clark, B., \& Hermele, K. (2013). Introduction: Ecology and power. In A. Hornborg, B. Clark, \& K. Hermele (Eds.), Ecology and power: Struggles over land and material resources in the past, present and future (Vol. 18). Routledge.

Hughes, T. P., Kerry, J. T., Álvarez-Noriega, M., Álvarez-Romero, J. G., Anderson, K. D., Baird, A. H., Bridge, T. C., et al. (2017). Global warming and recurrent mass bleaching of corals. Nature, 543(7645), 373-377. https://doi.org/ $10.1038 /$ nature 21707

Hviding, E. (1996). Guardians of Marovo lagoon: Practice, place, and politics in maritime Melanesia (Vol. 14). University of Hawaii Press.

Ingold, T. (2015). The life of lines. Routledge.

Ingold, T. (2018a). Anthropology: Why it matters. Polity Press.

Ingold, T. (2018b). Evolution in the minor key. In A. Fuentes \& C. DeaneDrummond (Eds.), Evolution of wisdom: Major and minor keys (pp. 115-123). Center for Theology Science and Human Flourishing, University of Notre Dame.

Jentoft, S. (2000). Legitimacy and disappointment in fisheries management. Marine Policy, 24(2), 141-148.

Jentoft, S. (2019). Life above water: Essays on human experiences of small-scale fisheries. In TBTI Global Book Series 1. Global.

Johnson, D. S. (2018). The values of small-scale fisheries. In D. S. Johnson, T. G. Acott, N. Stacey, \& J. Urquhart (Eds.), Social wellbeing and the values of small-scale fisheries (pp. 1-21). Springer.

Johnson, D. S., Bavinck, M., \& Veitayaki, J. (2005). Fish capture. In J. Kooiman, M. Bavinck, S. Jentoft, \& R. Pullin (Eds.), Fish for life: Interactive governance for fisheries (pp. 71-91). University of Amsterdam Press.

Johnson, D. S., Acott, T. G., Stacey, N., \& Urquhart, J. (Eds.). (2018). Social wellbeing and the values of small-scale fisheries. Springer.

Jouffray, J.-B., Blasiak, R., Norström, A. V., Österblom, H., \& Nyström, M. (2020). The blue acceleration: The trajectory of human expansion into the ocean. One Earth, 2(1), 43-54.

Kelleher, K., Westlund, L., Hoshino, E., Mills, D., Willmann, R., de Graaf, G., Brummett, R. (2012). Hidden harvest: The global contribution of capture fisheries. Report no. 66469-GLB. World Bank.

Kooiman, J., Jentoft, S., Bavinck, M., \& Pullin, R. (Eds.). (2005). Fish for life: Interactive governance for fisheries. Amsterdam University Press.

Kraan, M., \& Linke, S. (2020). Commentary 2 to the manifesto for the marine social sciences: Applied social science. Maritime Studies, 19(2), 129-130. 
Lam, V. W., Allison, E. H., Bell, J. D., Blythe, J., Cheung, W. W., Frölicher, T. L., Sumaila, U. R., et al. (2020). Climate change, tropical fisheries and prospects for sustainable development. Nature Reviews Earth \& Environment, $l(9), 440-454$.

Le Billon, P., \& Duffy, R. V. (2018). Conflict ecologies: Connecting political ecology and peace and conflict studies. Journal of Political Ecology, 25(1), 239-260. https://doi.org/10.2458/v25il.22704

Le Manach, F., Jacquet, J. L., Bailey, M., Jouanneau, C., \& Nouvian, C. (2020). Small is beautiful, but large is certified: A comparison between fisheries the marine stewardship council (MSC) features in its promotional materials and MSC-certified fisheries. PLoS One, 15(5), e0231073. https://doi.org/ 10.1371 /journal.pone. 0231073

Li, T. M. (2007). The will to improve: Governmentality, development, and the practice of politics. Duke University Press.

Longo, S. B., Clausen, R., \& Clark, B. (2015). The tragedy of the commodity: Oceans, fisheries, and aquaculture. Rutgers University Press.

Lowe, C. (2000). Global markets, local injustice in southeast Asian seas: The live fish trade and local fishers in the Togean Islands of Sulawesi. In C. Zerner (Ed.), People, plants, and justice: The politics of nature conservation (pp. 234-258). Columbia University Press.

Mansfield, B. (2004). Rules of privatization: Contradictions in neoliberal regulation of North Pacific fisheries. Annals of the Association of American Geographers, 94(3), 565-584. https://doi.org/10.1111/j.1467-8306.2004.00414.x

McCarthy, J. F. (2010). Processes of inclusion and adverse incorporation: Oil palm and agrarian change in Sumatra, Indonesia. The Journal of Peasant Studies, 37(4), 821-850. https://doi.org/10.1080/03066150.2010.512460

McGoodwin, J. R. (1995). Crisis in the world's fisheries: People, problems, and policies. Stanford University Press.

Mosse, D. (2010). A relational approach to durable poverty, inequality and power. The Journal of Development Studies, 46(7), 1156-1178. https://doi.org/1 $0.1080 / 00220388.2010 .487095$

Neumann, R. P. (2009). Political ecology: Theorizing scale. Progress in Human Geography, 33(3), 398-406. https://doi.org/10.1177/0309132508096353

Pálsson, G. (1994). Coastal economies, cultural accounts: Human ecology and Icelandic discourse. Manchester University Press.

Peet, R., \& Watts, M. (Eds.). (1996). Liberation ecologies: environment, development, social movements. Routledge.

Perreault, T., Bridge, G., \& McCarthy, J. (Eds.). (2015). The Routledge handbook of political ecology. Routledge.

Pikitch, E. K., Santora, C., Babcock, E. A., Bakun, A., Bonfil, R., Conover, D. O., Houde, E. D., et al. (2004). Ecosystem-based fishery management. Science, 305(5682), 346-347. https://doi.org/10.1126/science.1098222 
Pollnac, R. B., \& Poggie, J. J. (2008). Happiness, well-being and psychocultural adaptation to the stresses associated with marine fishing. Human Ecology Review, 15(2), 194-200.

Probyn, E. (2016). Eating the ocean. Duke University Press.

Robbins, P. (2012). Political ecology: A critical introduction (Vol. 16, 2nd ed.). John Wiley \& Sons.

Rocheleau, D., Thomas-Slayter, B., \& Wangari, E. (Eds.). (1996). Feminist political ecology: Global issues and local experience. Routledge.

Rousseau, Y., Watson, R. A., Blanchard, J. L., \& Fulton, E. A. (2019). Evolution of global marine fishing fleets and the response of fished resources. Proceedings of the National Academy of Sciences, 116(25), 12238-12243. https://doi. org/10.1073/pnas.1820344116

Scoones, I. (2009). Livelihoods perspectives and rural development. The Journal of Peasant Studies, 36(1), 171-196. https://doi.org/10.1080/ 03066150902820503

Silver, J. J., Gray, N. J., Campbell, L. M., Fairbanks, L. W., \& Gruby, R. L. (2015). Blue economy and competing discourses in international oceans governance. The Journal of Environment \& Development, 24(2), 135-160. https://doi. org/10.1177/1070496515580797

Song, A. M. (2018). How to capture small-scale fisheries' many contributions to society?-Introducing the 'value-contribution matrix' and applying it to the case of a swimming crab fishery in South Korea. In D. Johnson, T. Acott, N. Stacey, \& J. Urquhart (Eds.), Social wellbeing and the values of small-scale fisheries (pp. 125-146). Springer.

Spoehr, A. (1984). Change in Philippine capture fisheries: An historical overview. Philippine Quarterly of Culture and Society, 12(1), 25-56.

Steenbergen, D. J., Fabinyi, M., Barclay, K., Song, A. M., Cohen, P. J., Eriksson, H., \& Mills, D. J. (2019). Governance interactions in small-scale fisheries market chains: Examples from the Asia-Pacific. Fish and Fisheries, 20(4), 697-714. https://doi.org/10.1111/faf.12370

Stoll, J. S., Crona, B. I., Fabinyi, M., \& Farr, E. R. (2018). Seafood trade routes for lobster obscure teleconnected vulnerabilities. Frontiers in Marine Science, 5, 239. https://doi.org/10.3389/fmars.2018.00239

Tomiyama, I. (2002). The 'Japanese' of Micronesia: Okinawans in the Nanyô Islands. In R. Y. Nakasone (Ed.), Okinawan diaspora. University of Hawai'i Press.

Too Big to Ignore. (2013). Too Big to Ignore. Retrieved February 5, 2021, from http://toobigtoignore.net/

Voyer, M., Quirk, G., McIlgorm, A., \& Azmi, K. (2018). Shades of blue: What do competing interpretations of the blue economy mean for oceans governance? Journal of Environmental Policy \& Planning, 20(5), 595-616. https://doi. org/10.1080/1523908X.2018.1473153 
Warren, J. F. (1981). The Sulu zone, 1768-1898: The dynamics of external trade, slavery, and ethnicity in the transformation of a southeast maritime state. Singapore University Press.

Weeratunge, N., Béné, C., Siriwardane, R., Charles, A., Johnson, D., Allison, E. H., Badjeck, M. C., et al. (2014). Small-scale fisheries through the wellbeing lens. Fish and Fisheries, 15(2), 255-279. https://doi.org/10.1111/faf.12016

Whitehead, A. N. (1929). Process and reality: An essay in cosmology. Cambridge University Press.

Wolf, E. R. (1983). Europe and the people without history. University of California Press.

Open Access This chapter is licensed under the terms of the Creative Commons Attribution 4.0 International License (http://creativecommons.org/licenses/ by $/ 4.0 /$ ), which permits use, sharing, adaptation, distribution and reproduction in any medium or format, as long as you give appropriate credit to the original author(s) and the source, provide a link to the Creative Commons licence and indicate if changes were made.

The images or other third party material in this chapter are included in the chapter's Creative Commons licence, unless indicated otherwise in a credit line to the material. If material is not included in the chapter's Creative Commons licence and your intended use is not permitted by statutory regulation or exceeds the permitted use, you will need to obtain permission directly from the copyright holder. 